\section{Antecedents of organisational professional conflict faced by professional accountants in different work settings}

\author{
Itsaso Barrainkua ${ }^{1}$ \\ Marcela Espinosa-Pike ${ }^{1}$ \\ ${ }^{1}$ University of the Basque Country, Department \\ of Financial Economics, Bilbao, Spain
}

Recebimento:

08/20/2019

Aprovação:

$01 / 21 / 2020$

Editor responsável:

Prof. Dr. Leire San-Jose

Avaliado pelo sistema:

Double Blind Review

\begin{abstract}
Purpose - The aim of this study is to examine the effects of public interest commitment, professional commitment, organisational commitment, and organisational ethical culture on organisational professional conflict (OPC). The study also tests for the differences in the perception of OPC among professionals in different work settings: (i) professional accountants in business practice, (ii) tax and accounting advisors, and (iii) auditors.
\end{abstract}

Design/methodology/approach - This study is based on a questionnaire distributed among 779 Spanish professional accountants.

Findings - The findings show a negative relationship between both individuals' organisational commitment and OPC and between a strong organisational ethical culture and OPC. Professional accountants working in different settings exhibit differences in their perception of OPC; tax/accounting advisors perceive OPC to a higher extent.

Originality/value - This is the first study that analyses the effect of organisational ethical culture, together with professional and organisational commitment, on the perception of pressures arising from OPC among professional accountants in different work settings. Identifying antecedents of the conflicts that professional accountants may face has implications for organisations' human resource management and for the quality of the services provided. This study emphasizes the need for future studies to examine the differences in the work context of the different professional accountants.

Keywords - organisational professional conflict, professional accountants, professional commitment, organisational commitment, organisational ethical culture.

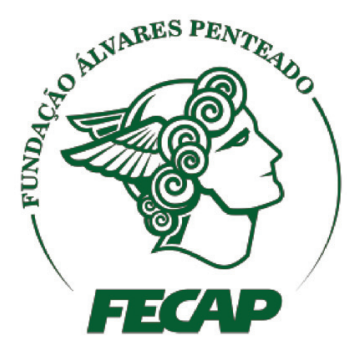

Revista Brasileira de Gestáo de Negócios

DOI: $10.7819 /$ rbgn.v22i3.4068 


\section{Introduction}

In the last three decades, many academics have expressed concern about the commercialisation of the accounting profession (Gendron, Suddaby, \& Lam, 2006; Sikka, 2004; Wyatt, 2004). In this regard, the business culture that has permeated accounting practice, both at the firm and professional level, is presumed to be inconsistent with professional accountants' traditional values. Currently, professional accountants are employed in bureaucratic and commercially oriented workplaces, which expose them to organisational and managerial authority (Muzio \& Kirkpatrick, 2011). The context in which the professional practice is carried out may lead accountants to subordinate the values of their profession to meet the goals of the organisation.

This empirical research draws on perspectives of social identity theory and sociology of the professions to analyse the potential conflict between competing professional and organisational demands.

Social identity theory acknowledges that individuals have both a personal and a social identity (Ashforth \& Mael 1989; Brouard, Bujaki, Durocher, \& Neilson, 2017) and provides an understanding of the role of the conflict that an individual may experience. Given that professionals belong to a number of different groups (organisation, profession, etc.), their social identity consists of a mix of different identities that may impose inconsistent demands upon the professional. Furthermore, these demands can come into conflict with the professional's personal identity (Ashforth \& Mael, 1989).

Based on the perspective of sociology of the professions, this study focuses on accountants' professional attitudes, such as professional commitment and public interest commitment, which reflect the perception of their professional role and the sources of their identity. Historically, professionalism emphasizes the notion of the social function, in which the professional is described as a guardian of the public interest (Freidson,
2001; Suddaby, Gendron, \& Lam, 2009). However, the discussion around professionalism has pointed to the potential problems that arise when accountants work in bureaucratic contexts that emphasize profit at the expense of their professional values (Suddaby et al., 2009; Wyatt, 2004).

Previous studies have jointly investigated the organisational and professional commitment of accounting professionals as well as the potential conflict that may arise between the two commitments, referred to as organisational professional conflict (OPC) (Aranya \& Ferris, 1984; Shafer, 2009). Therefore, the concept of OPC describes the potential collision between professional values and organisational goals and values (Aranya \& Ferris, 1984; Aranya, Pollock, \& Amernic, 1981; Shafer, 2009; Shafer, Poon, \& Tjosvold, 2013).

One of the main reasons for the interest in studying OPC lies in the negative outcomes of this phenomenon. Most studies have found that OPC is associated with dysfunctional consequences, such as a reduction in job satisfaction, an increase in professional as well as organisational turnover intentions (Bamber \& Iyer, 2002; Hall, Smith, \& Langfield-Smith, 2005; Shafer, Lowe, \& Fogarty, 2002), and damage to the quality of job performance (McManus \& Subramaniam, 2014).

OPC reflects the pressure to compromise professional standards when organisational values or expectations are in conflict with professional values (Shafer, 2002; Shafer, 2009). In the present study, we address OPC by examining the organisational pressures faced by accountants to breach professional standards.

The aim of this study is to examine the effects of public interest commitment, professional commitment, organisational commitment, and organisational ethical culture on the perception of OPC. In the study, we also test for the differences in the perception of OPC between professionals in different accounting areas.

Studying the pressure that accountants may face is of utmost importance to help 
reduce dysfunctional outcomes in accounting practice. However, there are relatively few recent empirical studies that examine the professional and organisational commitment of accountants (Shafer, 2009) and the pressures that may arise from a conflict between these two commitments. Therefore, this study makes several contributions to the international accounting literature.

The literature in the area has focused mainly on two antecedents of OPC: organisational and professional commitment. However, some researchers (Shafer, 2009; Shafer et al., 2013) call for new empirical studies that place more emphasis on the organisational characteristics of the firms where accountants conduct their work, such as the ethical climate of the organisation. The studies conducted by Shafer (2009) and Shafer et al. (2013) appear to be the first attempts in the accounting literature to investigate the association between organisational ethical climate and organisational-professional conflict. However, these studies were limited to professionals in public accounting firms in Asian contexts. To address this shortcoming of the existing literature and extend previous research (Shafer, 2009; Shafer et al., 2013), the present study analyses the effect of professional and organisational commitment, together with the organisational culture of the firm, on the perception of pressures arising from OPC in the case of professional accountants in different work settings.

Moreover, in the scarce literature that exists in this area, hardly any studies have investigated OPC in the case of other accounting professionals besides auditors (Shafer, 2009). This study is one of the first to compare the OPC among professional accountants in different work settings. A few studies (Aranya \& Ferris, 1984; Suddaby et al., 2009) have compared the professional values of accountants employed in organisations (professional accountants in business), where these accountants work in firms providing professional services, such as auditing, or tax and accounting consulting (professional accountants in practice). While the collective of professional accountants in practice has usually been studied as a single and homogeneous group, this study differentiates between auditors and accounting and tax advisors. This division is crucial for the case of Spain and most European countries, where the current structure of the accounting profession is noticeably different to the commonly studied Anglo-American contexts (Hall et al., 2005; Shafer, 2009). In common law countries or Anglo-American contexts, all accountants are included in the official professional title of Chartered Accountant or Certified Public Accountant, which includes auditors as well. However, in countries where the legal system is based on Roman law, such as in many European countries, there is a specific official title for auditors. These professionals are differentiated from accounting experts who provide tax and accounting advisory services (Amat \& Bové, 2015) and the responsibilities associated with each professional title are different. Therefore, understanding the pressures accountants in different work settings face in different national contexts to the ones commonly studied contributes to the international behavioural accounting literature and is fundamental for establishing mechanisms to strengthen the quality of all the services accountants provide.

This study is based on a questionnaire distributed in 2015 among 779 Spanish professional accountants in different work areas: (i) professional accountants in business practice (employees in the financial department of a company), (ii) professional accountants working as tax and accounting consultants and (iii) auditors.

The results of the study indicate a negative relationship between individuals' organisational commitment and their perception of OPC. Moreover, the results reveal a negative relationship between a strong organisational ethical culture and the OPC perceived. This study shows the existence of differences among the pressures perceived by accountants in different work settings. It reveals that professional accountants 
in businesses working as tax and accounting consultants perceive higher OPC than auditors and accountants employed in an organisation.

This study has several practical implications for organisations employing accountants as well as for the profession as a whole. Identifying antecedents of the conflicts that accountants may face has important implications for human resource management within organisations providing accounting services, such as audit firms, as well as tax and accounting consulting companies. Personnel shortages and high employee turnover have been highlighted as significant threats to the future of audit firms and the accounting profession. Given that the literature has found that the pressures stemming from OPC are related to accountant retention (Hall et al., 2005; Shafer, 2002), studies analysing the causes of this phenomenon are of primary interest.

The remainder of this paper is organised as follows. The next section reviews the previous literature and develops our research hypotheses. The third section addresses our research method, and the fourth section reports our results. Finally, in the fifth section, we present our study's primary conclusions, as well as the limitations and future lines of research.

\section{Literature Review and Hypotheses Development}

\section{I Public interest commitment}

Several studies (Bamber \& Iyer, 2002; Davenport \& Dellaportas, 2009; Suddaby et al., 2009) have claimed that little attention has been paid to how much accountants accept and acknowledge core professional values and commitments. Most studies that have addressed accountants' professionalism have been limited to analysing accountants' professional commitment, without specifically addressing their social obligation. Public interest commitment involves accountants' willingness to protect the interests of third parties who rely on the opinions and advice delivered by accounting professionals (Davenport \& Dellaportas, 2009; Parker, 1987).

The functionalist view of professionalism in the literature in the field of sociology of professions indicates that professionals are distinguished from other workers by their commitment to serving the public interest rather than pursuing only their own economic interests (Freidson, 1989; Larson, 1977; Parsons, 1939).

We propose that accountants' public interest commitment will influence the way in which they identify and respond to organisational pressures. If accountants believe their role is to serve the public interest and meet society's expectations, they could be expected to be more successful in fulfilling their responsibility of ensuring the fair presentation of financial statements. Therefore, these professionals may be more resistant to organisational pressures to breach professional standards. In contrast, if accountants see their principal role as being to serve their firms' and clients' interests rather than protecting the interests of other users of financial information, this could influence what they believe are acceptable actions (Cooper \& Robson, 2006; Davenport \& Dellaportas, 2009), and, therefore, they may not perceive organisational pressures as being in conflict with their professional values.

Therefore, we propose the following hypothesis:

H1: There is a positive relationship between accountants' public interest commitment and perceived OPC.

\subsection{Professional commitment}

Professional commitment represents the attachment or loyalty that individuals form with respect to their profession (Gendron, Suddaby, \& Qu, 2009; Hall et al., 2015). The professional commitment construct is developed based on that of organisational commitment (Mowday, Steers, $\&$ Porter, 1979) and reflects a strong belief in and acceptance of the profession's goals and values, a 
willingness to exert considerable effort on behalf of the profession, and a strong desire to maintain membership of the profession (Aranya \& Ferris, 1984; Lord \& DeZoort, 2001; Porter, Steers, Mowday, \& Boulian, 1974; Suddaby et al., 2009).

Based on arguments from social identity theory, accountants who identify with their profession tend to internalize the values and norms of the profession, and therefore, their behaviour is guided by these values (Svanberg \& Ohman, 2015).

In this regard, high professional commitment has been linked to positive outcomes, such as improved job satisfaction, less likelihood of leaving the profession, and improved job performance (Hall et al., 2005).

Prior studies that have analysed the relationship between professional commitment and OPC have presented mixed results. Aranya and Ferris (1984) and Harrell, Chewning and Taylor (1986) found that accountants who are highly committed to both their profession and organisation perceived lower OPC. McGregor, Killough and Brown (1989) reported a positive relationship between OPC and professional commitment for management accountants. However, Meixner and Bline (1989) did not find any relationship between professional commitment and OPC. In a more recent study, Shafer et al. (2002) found that management accountants' dedication to the profession and demands for autonomy were positively related to OPC.

In line with the previous hypothesis, we propose that accountants who are more committed to their profession and have thus internalised its goals and values and feel a strong affiliation should be more wary of the organisational pressures that place them in conflict with these values.

H2: There is a positive relationship between accountants' professional commitment and perceived OPC.

\subsection{Organisational commitment}

According to Mowday et al. (1979), organisational commitment reflects '(1) a strong belief in and acceptance of the organisation's goals and values, (2) a willingness to exert considerable effort on behalf of the organisation, and (3) a strong desire to maintain membership in the organisation'. Organisational commitment increases as a result of the socialisation process occurring within the employing organisation (Fogarty, 1992).

Early accounting studies that addressed the OPC phenomenon assumed that professional and organisational commitment were inherently incompatible (Hall, 1967; Shafer et al., 2013). However, more recent studies reveal that there is a positive relationship between these two constructs (Hall et al., 2005; Shafer et al., 2013). Therefore, accounting professionals experience no intrinsic conflict between maintaining the commitment to their profession and the commitment to the business organisation where they are employed.

Organisational commitment reflects an individual's identification with their organisation (Aranya \& Ferris, 1984) and, accordingly, accountants who strongly identify with their organisation are expected to adopt the perspective of the organisation (Hiller, Mahlendorf, \& Weber, 2014). Therefore, accountants with high organisational commitment may ignore the conflict between professional and organisational goals (Aranya \& Ferris, 1984). Moreover, professionals tend to show higher commitment to an organisation whose goals match their professional values (Garcia-Falières \& Herrbach, 2015). Therefore, a low perception of pressures and a high organisational commitment would be related. In this regard, several studies (Bamber \& Iyer, 2002; Shafer et al., 2002) have found a significant negative relationship between organisational identification or commitment and the perception of OPC. Therefore, we propose the following hypothesis: 
H3: There is a negative relationship between accountants' organisational commitment and perceived OPC.

\subsection{Organisational ethical culture}

Treviño (1990) defines ethical culture as 'a complex interplay of formal and informal systems that can support either ethical or unethical organisational behaviour'. In firms whose ethical cultures are strong, ethical norms support ethical conduct, organisational leaders encourage ethical behaviour, and this behaviour is rewarded whereas unethical behaviour is punished (Treviño, Butterfield, \& McCabe, 1998). Studies in the behavioural accounting literature have adopted both organisational ethical climate and organisational ethical culture to measure the organisational policies or practices that influence employees' ethical decisions. In this study, we focus on the broader construct of organisational ethical culture.

Analysing the influence of organisational ethical culture has practical implications for the profession, as an organisation's ethical culture can be influenced by the steps taken by the organisation itself (Shafer \& Simmons, 2011; Shafer et al., 2013; Treviño et al., 1998). Firms' managers have more control over their organisational environment than over employees' values (Treviño et al., 1998). Accordingly, the quality of accountants' reporting decisions can be improved if audit firms align their organisational values with those of the broader accounting profession (Shafer, 2015).

Ethical culture establishes what is considered acceptable behaviour within an organisation (Treviño et al., 1998). Therefore, the presence of a strong ethical environment in the firm induces accountants to act ethically and reduces the tendency to act in self-interest and breach professional standards (Barrainkua \& Espinosa-Pike, 2018; Douglas, Davidson, \& Schwartz, 2001; Svanberg \& Ohman, 2016). Several international studies (Bamber \& Iyer,
2009; Shafer, 2009; Shafer et al., 2013) have revealed that accountants employed in public accounting firms whose ethical climates do not support professional values experience conflicts between their organisational and professional goals. Similarly, Shafer and Wang (2010) found that accountants employed in organisations that have a strong ethical culture, which provides support for the ethical norms and values of the accounting profession, perceive lower levels of OPC. We suggest that if a firm has a strong ethical culture, the ethical values that the top management promotes via formal and informal communications will encourage compliance with professional standards. Therefore, accountants who perceive an ethical culture in their organisation will feel less pressure to compromise professional standards.

H4: There is a negative relationship between perceived organisational ethical culture and perceived OPC.

\subsection{The professional accountant's work area}

The literature on pressures perceived by accounting professionals (Espinosa-Pike \& Barrainkua, 2016; Espinosa-Pike \& Barrainkua, 2017; Hatfield, Jackson, \& Vandervelde, 2011; Lord \& DeZoort, 2001) reveals that most professionals are pressured, both by their superiors and by their clients, to act in a way that compromises their ethical values and professional standards.

Although the accounting literature has mainly focused on the case of auditors (Shafer et al., 2013), all professional accountants' primary role is to serve the public interest (International Federation of Accountants - IFAC, 2016). Given the diversity of professionals acting as professional accountants, it seems reasonable that the intensity and nature of the pressures that arise from OPC will vary among different groups. There are several reasons to speculate that the perceived OPC will be different between accountants in different work settings. 
Accountants working in industry have a different sense of responsibilities than those working in accounting firms (Cooper \& Robson, 2006). Although all professional accountants' primary obligation is to the public, their particular relationship with their employing firm gives them a different set of responsibilities (Duska, Duska, \& Kury, 2018). Auditors, as well as accounting and tax advisors, are employees of accounting service firms and the clients to whom they provide their services are other companies. However, management accountants are employees of the company for whom they prepare financial statements. Consequently, they are also expected to be loyal to their employing organisation, and this situation may result in a conflict of interests.

Auditors are employed in audit firms, which are owned and managed by other auditors; therefore, the control of the organisation remains among professionals. Auditing law in Spain, like in many other countries, specifically states that audit firms must belong mostly to licensed auditors. We can presume that these organisations provide more autonomy and that their goals are more aligned with those of the profession compared to management accountants employed in business organisations (Shafer, 2002).

Moreover, there is greater homogeneity among the personnel of audit firms, and these personnel have a greater connection to the accounting profession, in terms of training background, work area, and functions, compared to professional accountants in business or those employed as tax and accounting advisors (Gendron et al., 2006).

Aranya and Ferris (1984) found that government and industry accountants experienced higher levels of OPC than auditors. The same authors also reported that auditors tended to show higher professional as well as organisational commitment, which suggested greater value congruence in public accounting firms. However, Shafer et al. (2013) compared the perception of OPC among auditors, taxation specialists, consultants, and employees of a firm's accounting services and did not find significant differences between these different working specialisations. The mixed results reported in both studies could be explained by the change of the work context in public accounting firms. The diversification of services may have weakened the professional goal orientation in these firms and, therefore, the level of OPC among public accountants may have increased (Gendron et al., 2006).

A recent study (Espinosa-Pike \& Barrainkua, 2019) found that auditors perceived less pressure to breach professional standards compared to accounting and tax consultants as well as accountants working in the financial department of their organisation.

In the present study, we aim to investigate the different perceptions of pressures due to conflicting professional and organisational goals between accountants' work settings. We propose the following hypothesis:

H5: The perceived OPC of auditors is statistically lower than that of accountants in other work settings (employees in a company's financial department and professional accountants working as tax and accounting advisors).

\section{Methodology}

\section{I Sample and data collection}

To test the hypotheses stated above, we employed a survey as the research instrument. The survey was distributed to professional accountants who were members of the Spanish professional organisation Consejo General de Economistas. This institution coordinates and represents the Colleges of Economists in Spain and its aims are to organise the profession and defend the professional interests of its members.

Before distributing the questionnaire, a pilot test was conducted among various groups of the population under study. First, the questionnaire was sent to a partner of a public accounting firm, who passed it on to a few fellow 
auditors. We then arranged an interview with this contact partner, in order to gain feedback on the questionnaire from the group of respondents. The contact auditor indicated that, overall, neither he nor his colleagues had any trouble understanding the questions. The questionnaire was also reviewed by accounting experts who were members of the Consejo General de Economistas as well as by university lecturers who taught accounting, none of whom exhibited any comprehension difficulties. Only slight changes were made to the initial questionnaire, most of which were attempts to remove minor ambiguities.

The final survey was distributed in February 2015 among the approximately 7,500 members of the Consejo General de Economistas. The responses were collected through online survey software. Taking into account that the professionals were questioned about real-life sensitive issues, as well as the strengths associated with online survey studies, such as ensuring anonymity and the possibility of reaching a large population, we considered this method the most feasible for the distribution of the questionnaire.

A total of 974 usable responses were obtained, which represents a response rate of $13 \%$. The economists who participated in the study come from different professional settings, such as auditing, accounting, and tax consulting in different company departments (financial, commercial, human resources, etc.) and academia, among others. In order to fulfil the objectives of the study, only the professionals related to the financial area were selected, specifically accounting professionals within the financial department of a company, accounting and tax advisors, and auditors. Therefore, the final sample of this study comprises 778 participants.

\subsection{Questionnaire and measurement of variables}

The first part of the questionnaire contained general questions about the characteristics of the respondents. Following this, the questionnaire included a series of closed-ended questions concerning the variables under study:

$O P C$. This variable captures the perception of the pressures felt by professional accountants due to conflicting professional and organisational values. The participants of the study were asked about eight different pressures they face to breach professional standards. These were selected based on instruments previously used in the academic literature on ethical behaviour in accounting and auditing (Shafer \& Simmons, 2011; EspinosaPike $\&$ Barrainkua, 2016) and in the International Code of Ethics for Professional Accountants (IFAC, 2016). The respondents indicated the frequency with which they had perceived eight pressures (see Appendix), on a scale of 1 (never) to 7 (nearly always). A confirmatory factor analysis (not tabulated) revealed that all pressures were loaded in one factor.

Public Interest Commitment. This variable assesses the degree to which the respondents believed that serving the public interest is an accountant's primary role. This variable was used before by Bobek, Hageman, and Radtke (2015). The participants had to indicate how much they agreed or disagreed with a statement (see Appendix) on a Likert scale, ranging from 1 (completely disagree) to 7 (completely agree).

Professional Commitment. This variable was measured using the instrument developed by Porter et al. (1974) for organisational commitment, adapted to measure professional commitment by Aranya et al. (1981). This scale has been used in many studies in the field (Lord \& DeZoort, 2001; Suddaby et al., 2009). The participants had to indicate how much they agreed or disagreed with three statements (see Appendix) on a Likert scale, ranging from 1 (completely disagree) to 7 (completely agree). This reduced version of the scale of professional commitment has been used in previous studies, such as the one by McManus and Subramaniam (2014).

Organisational Commitment. This variable is based on the instrument developed by Porter et al. (1974), which has been used in many studies in the accounting field (Aranya \& Ferris, 1984; 
Lord \& DeZoort, 2001; Suddaby et al., 2009). The participants had to indicate how much they agreed or disagreed with three statements (see Appendix) on a Likert scale, ranging from 1 (completely disagree) to 7 (completely agree). This reduced version of the scale has been used in previous studies (McManus \& Subramaniam, 2014).

Organisational Ethical Culture. An 11-item scale was included in the questionnaire to measure the perceived ethical culture of the respondents' organisations. This scale was adapted from the ethical environment instrument developed by Treviño et al. (1998), which has been proven to be reliable in accounting settings (Barrainkua \& Espinosa-Pike, 2015; Shafer \& Wang, 2010; Shafer \& Simons, 2011). The ethical environment dimension proposed by Treviño et al. (1998) consisted of 14 items. For the purposes of the present study, only eight items, OEC-1 through to OEC-8, were included. As in the original instrument, these eight items refer to the rewards/ punishments for ethical/unethical actions and to top management role modelling. In addition, two more items that could be relevant in the accounting field were included: 'Top managers in this organisation are concerned with informing employees about the ethics code' (OEC-9) and 'Top managers in this organisation promote the ethical training of employees' (OEC-10). These items have been employed as proxies for an ethical environment in previous studies (Barrainkua \& Espinosa-Pike, 2015; Martinov-Bennie \& Pflugrath, 2009).

Principal component factor analysis was used to test the dimensionality of the ethical culture scale. The final factor solution is shown in Table 1. The results reveal two factors with eigenvalues greater than one. All items were loaded above 0.5 for each factor, and there were no cross-loadings over 0.3 . These two factors explained $75 \%$ of the variance, and the first factor included seven items that reflect the general ethical environment of the organisation. Therefore, in accordance with previous authors (Treviño et al., 1998), we refer to this factor as ethical environment, which explains $62 \%$ of the variance and has an internal reliability of 0.95 . Three items were loaded in factor 2 . These were the reverse-scored statements OEC6, OEC 7 and OEC8, the items on the promotion of unethical behaviour. This factor explains $13 \%$ of the variance and has an internal reliability of 0.78 .

Table 1

\section{Summary of factor loadings for organisational ethical culture scale}

\begin{tabular}{|c|c|c|}
\hline & \multicolumn{2}{|c|}{ Factor loadings } \\
\hline & 1 & 2 \\
\hline The management in this organisation disciplines unethical behaviour when it occurs (OEC-1) & 0.843 & -0.021 \\
\hline People with integrity are rewarded in this organisation (OEC-2) & 0.838 & 0.025 \\
\hline Top managers of this organisation regularly show that they care about ethics (OEC-3) & 0.884 & 0.062 \\
\hline Ethical behaviour is the norm in this organisation (OEC-4) & 0.867 & 0.102 \\
\hline The top management of this organisation guides decision making in an ethical direction (OEC-5) & 0.851 & 0.088 \\
\hline $\begin{array}{l}\text { Employees in this organisation perceive that people who violate the ethics code still get rewards (OEC-6 } \\
\text { reverse scored) }\end{array}$ & -0.162 & 0.910 \\
\hline The ethics code only serves to maintain the organisation's public image (OEC-7 reverse scored) & 0.147 & 0.751 \\
\hline Top managers in this organisation are models of unethical behaviour (OEC-8 reverse scored) & 0.047 & 0.819 \\
\hline Top managers in this organisation are concerned with informing employees about the ethics code (OEC-9) & 0.888 & -0.093 \\
\hline Top managers in this organisation promote the ethical training of employees (OEC-10) & 0.914 & -0.115 \\
\hline Percentage of variance explained & $62 \%$ & $13 \%$ \\
\hline Cronbach's alpha & 0.95 & 0.78 \\
\hline
\end{tabular}




\subsection{Participant characteristics}

A total of 778 responses were included in this study. General characteristics of the respondents are shown in Table 2.

The average age of the professional accountants was 49 . The majority of those participating in this study were male $(78 \%)$, with female respondents representing less than a quarter of the total sample.

Table 2

\section{Characteristics of the participants}

\begin{tabular}{lcc}
\hline Age (mean) & 49 \\
Gender & $\%$ & $\mathrm{~N}$ \\
Female & $22 \%$ & 171 \\
Male & $78 \%$ & 608 \\
\hline Occupation & $\%$ & $\mathrm{~N}$ \\
\hline Professional accountant in business practice - Employees in the financial department of a company & $20 \%$ & 156 \\
Professional accountant working as tax and accounting consultant & $59 \%$ & 459 \\
Auditor & $21 \%$ & 164 \\
\hline Total sample & & 779 \\
\hline
\end{tabular}

\section{Results}

\section{I Descriptive statistics and t-test results}

First, Table 3 displays the descriptive statistics and one sample t-test results for the variables in the study. These were measured by combining the responses to the statements shown in the Appendix. The Cronbach's alpha
The respondents were categorised by their current occupation within the accounting profession. Table 2 shows that $20 \%$ of the respondents are employees in the financial department of a company, 59\% work as tax and accounting consultants for other client companies and, finally, $21 \%$ of the participants work as auditors.

Table 3

\section{Descriptive statistics and t-test results}

\begin{tabular}{|c|c|c|c|c|c|}
\hline & Cronbach's alpha & Mean & SD & t-test & Sign. \\
\hline Organisational-professional conflict & 0.904 & 2.537 & 1.401 & -29.132 & 0.000 \\
\hline Public interest commitment & n.a. & 4.804 & 1.776 & 12.626 & 0.000 \\
\hline Professional commitment & 0.814 & 6.022 & 1.002 & 56.328 & 0.000 \\
\hline Organisational commitment & 0.834 & 6.150 & 1.102 & 54.460 & 0.000 \\
\hline OEC Factor 1- Ethical environment & 0.947 & 3.907 & 0.884 & -2.948 & 0.003 \\
\hline $\begin{array}{l}\text { OEC Factor 2- Promotion of unethical behaviour } \\
\text { (reversed) }\end{array}$ & 0.782 & 5.911 & 0.959 & 55.616 & 0.000 \\
\hline
\end{tabular}

for the multi-item variables is over 0.70 (Table $3)$. The scales, therefore, show sufficient internal reliability. Compliance with key assumptions (linearity between the dependent and independent variables, constant error variance, and normality of the error distribution) was confirmed through appropriate tests. 
Table 3 shows that the professional accountants in the sample do not frequently perceive OPC when performing their duties.

The results suggest that the respondents understand their role as being to serve the public interest, as well as the need to preserve this above all other interests. Moreover, Table 3 reveals that the professional accountants in the sample show both a high professional commitment and a high organisational commitment.

Concerning the variables on organisational ethical culture, the responses suggest that accountants, in general, do not perceive the ethical environment of their firms as strong. However, the mean score for the promotion of unethical behaviour variable (reverse-scored) indicates that the participants do not perceive an unethical tone at the top in their organisations.

As one of the main objectives of this study is to analyse the differences in the perception of OPC between professionals in different accounting areas, we divided the sample based on the work activity performed by the participants. Accordingly, we calculated the mean response for the different groups and made a comparison of means using analysis of variance. The ANOVA test results are shown in Table 4.

Table 4

Descriptive statistics by work area and ANOVA test results

\begin{tabular}{lcccccc}
\hline & & Mean & & & ANOVA test & $\begin{array}{c}\text { (Post-hoc Tukey b } \\
\text { and Scheffe tests) }\end{array}$ \\
\hline & PAIB & $\begin{array}{c}\text { Tax/Accounting } \\
\text { consultant }\end{array}$ & Auditor & $\boldsymbol{F}$ & p-value & \\
\hline Organisational-professional conflict & 2.389 & 2.678 & 2.284 & 5.923 & $0.003^{* * *}$ & TAC > PAIB, A \\
$\begin{array}{l}\text { Public interest commitment } \\
\text { Professional commitment }\end{array}$ & 4.602 & 4.674 & 5.389 & 12.213 & $0.000^{* * *}$ & A PAIB, TAC \\
$\begin{array}{l}\text { Organisational commitment } \\
\text { OEC Factor 1- Ethical environment }\end{array}$ & 6.106 & 5.977 & 6.025 & 0.984 & $0,374 \quad$ NS \\
$\begin{array}{l}\text { OEC Factor 2- Promotion of unethical } \\
\text { behaviour (reversed) }\end{array}$ & 5.619 & 6.302 & 6.206 & 25.041 & $0.000^{* * *}$ & PAIB $<$ TAC, A \\
\hline
\end{tabular}

Nota. ${ }^{* * *}$ significant at the 0.01 level; NS not significant

Letters in the last column indicate the groups that present statistically significant differences based on the Tukey $\mathrm{b}$ and Scheffe test results, where: PAIB = professional accountant in business practice (employees in the financial department of a company), TAC = tax/accounting consultant, $\mathrm{A}=$ auditor.

Table 4 reveals that the tax and accounting consultants are the ones that perceive greater OPC. Furthermore, the auditors in the sample show statistically higher public interest commitment than the rest of the professional accountants. Professional accountants in business practice, that is, employees in the financial department of a company, show less organisational commitment than tax and/or accounting consultants and auditors. Moreover, these professionals perceive a lower organisational ethical culture than the consultants and auditors in the sample.

\subsection{Correlation and regression analyses}

\subsection{Correlation analysis}

To test the relationship among the variables under study a correlation analysis was carried out (Table 5). 
Table 5

Pearson's correlation coefficients and significance levels of dependent and independent variables

\begin{tabular}{|c|c|c|c|c|c|c|}
\hline & OPC & $\begin{array}{c}\text { Public } \\
\text { interest }\end{array}$ & $\begin{array}{l}\text { Professional } \\
\text { commitment }\end{array}$ & $\begin{array}{c}\text { Organisational } \\
\text { commitment }\end{array}$ & $\begin{array}{c}\text { Ethical } \\
\text { environment }\end{array}$ & $\begin{array}{c}\text { Promotion of } \\
\text { unethical behaviour } \\
\text { (reversed) }\end{array}$ \\
\hline OPC & 1 & $\begin{array}{c}-0,040 \\
(-0,268)\end{array}$ & $\begin{array}{l}-0,124^{* * *} \\
(0,001)\end{array}$ & $\begin{array}{c}-0,263^{* * *} \\
(0,000)\end{array}$ & $\begin{array}{c}-0,346^{* * *} \\
(0,000)\end{array}$ & $\begin{array}{c}-0,359^{* * *} \\
(0,000)\end{array}$ \\
\hline Public interest & & 1 & $\begin{array}{l}0,159^{* * *} \\
(0,000)\end{array}$ & $\begin{array}{c}0,033 \\
(0,363)\end{array}$ & $\begin{array}{c}0,039 \\
(0,272)\end{array}$ & $\begin{array}{c}0,000 \\
(0,999)\end{array}$ \\
\hline $\begin{array}{l}\text { Professional } \\
\text { commitment }\end{array}$ & & & 1 & $\begin{array}{l}0,408^{* * *} \\
(0,000)\end{array}$ & $\begin{array}{l}0,289^{* * *} \\
(0,000)\end{array}$ & $\begin{array}{l}0,174^{* * *} \\
(0,000)\end{array}$ \\
\hline $\begin{array}{l}\text { Organisational } \\
\text { commitment }\end{array}$ & & & & 1 & $\begin{array}{l}0,625^{* * *} \\
(0,000)\end{array}$ & $\begin{array}{l}0,412^{* * *} \\
(0,000)\end{array}$ \\
\hline $\begin{array}{l}\text { Ethical } \\
\text { environment }\end{array}$ & & & & & 1 & $\begin{array}{l}0,545^{* * *} \\
(0,000)\end{array}$ \\
\hline $\begin{array}{l}\text { Promotion } \\
\text { of unethical } \\
\text { behaviour } \\
\text { (reversed) }\end{array}$ & & & & & & 1 \\
\hline
\end{tabular}

Nota. ${ }^{* * *}$ significant at the 0.01 level

The Pearson's correlation coefficients in Table 5 reveal that OPC is negatively correlated with individuals' professional and organisational commitment as well as with the two variables representing an organisation's ethical culture.

Furthermore, the results show that professional commitment is positively related to public interest commitment and organisational commitment. The correlation matrix also reveals that professional and organisational commitment are both positively related to the organisation's ethical culture.

Finally, the two factors representing the firm's ethical culture are positively correlated.

\subsubsection{Regression analysis}

To test the hypotheses stated above, in this section we conducted a multiple regression analysis. To analyse if the perception of OPC differs between the three groups of professionals studied we included two dummy variables. The first one takes the value 1 if the individual is an auditor and 0 otherwise, and the second one takes the value 1 if the individual is a professional accountant in business practice employed in an organisation and 0 otherwise. In the regression model employed to test the hypotheses, we also controlled for individual differences in terms of age and gender.

The results are shown in Table 6 . 
Table 6

Regression results for the model, with dependent variable Perceived OPC

\begin{tabular}{lccc}
\hline Independent variable & Coefficient & SE & Sig.t \\
\hline Public Interest & -0.017 & 0.018 & 0.342 \\
Professional commitment & 0.032 & 0.036 & 0.381 \\
Organisational commitment & -0.084 & 0.043 & $0.049^{* *}$ \\
Ethical environment & -0.207 & 0.045 & $0.000^{* * *}$ \\
Promotion of unethical behaviour & -0.245 & 0.038 & $0.000^{* * *}$ \\
Auditor & -0.243 & 0.082 & $0.003^{* * *}$ \\
PAIB employee & -0.530 & 0.087 & $0.000^{* * *}$ \\
Age & -0.002 & 0.002 & 0.281 \\
Gender & 0.088 & 0.078 & 0.259 \\
Constant & 0.255 & 0.144 & $0.076^{*}$ \\
\hline
\end{tabular}

$R^{2}=0.206 ; \mathrm{Adj} . R^{2}=0.197 ; F=22.222 ; p=0.000$

Nota. * significant at the 0.1 level; ** significant at the 0.05 level; *** significant at the 0.01 level.

The multiple regression model is statistically significant at the 0.001 level and has an explanatory power of 0.197 . The results of the regression support hypothesis 3, confirming a negative relationship between individuals' organisational commitment and OPC. Hypothesis 4, which proposes a negative relationship between organisational ethical culture and OPC, is supported. Hypothesis 5 is also supported as statistically significant differences were found between professional accountants in different work settings. The multiple regression results reveal that professional accountants working as consultants perceived greater OPC than auditors and professional accountants employed in an organisation. Age and gender have no significant relationship with the perception of OPC, as the regression results were the same when these control variables were excluded from the model.

\section{Conclusion}

The aim of this study was to examine the effect of public interest commitment, professional commitment, organisational commitment, and organisational ethical culture on the OPC affecting accountants through their perception of the pressures they face to breach professional standards. In this study, we also tested the differences in the perception of OPC between professional accountants in different accounting areas.

The results of the study reveal that professional accountants identify significantly with their organisation, and, in addition, the results show that a negative relationship exists between individuals' organisational commitment and OPC. This result has important implications for human resource management. Considering that the literature has proven that a high organisational commitment and low OPC lead to higher job satisfaction and performance quality for professionals, it should be a company's primary objective to pursue the attachment of their employees to their organisation. To this end, the expected correlation between professional commitment and organisational commitment found in this study indicates the need to create a culture oriented towards professional values in the organisation.

Moreover, the findings also show a negative relationship between a strong organisational ethical culture and OPC. The fact that organisational ethical culture is a highly influential factor in accountants' perceptions of the pressures they face to breach professional standards emphasizes the need for common values that promote professional 
values in an organisation. Furthermore, given that the literature has shown a strong relationship between the perception of organisational pressures and dysfunctional behaviour, it could be expected that a strong ethical culture in professional and in non-professional organisations would help improve the quality of financial information.

The fact that this study has identified that organisational commitment and organisational ethical culture are antecedents of the conflicts that accountants face has important implications for companies' top management. Top management in audit firms play a pivotal role in fostering an ethical culture that highlights professional values, such as the public interest, which would ultimately lead to the fair presentation of financial statements.

The results of the study reveal significant differences in the perception of OPC between professional accountants in different work settings. Professional accountants working as tax and accounting consultants perceived greater OPC than auditors and accountants employed in an organisation. This result highlights the importance of paying special attention to accounting and tax advisors. These professionals are key to ensuring the reliability of financial information and to contributing to the transparency and proper functioning of the market. However, the work area of these professionals was not perceived as being linked to the traditional activities of the professional accountant, as was the case for the auditor. In Spain, until now, only auditors have organised themselves as a profession, and the auditor is the only professional figure related to accounting that is regulated in Spain. The recently regulated professional title in Spain of 'professional accountant', similar to the title that already existed in the rest of Europe, will provide a professional status to all accounting experts. In this sense, their activities will be subject to both private and public regulation, and also to access requirements, continuous training, and to a code of conduct regulating their behaviour. The results of our study ratify the need for accounting and tax advisors to work under the accredited title of professional accountant, which would entail the application of performance standards and uniform ethical requirements, helping professionals manage organisational pressures and the resulting OPC.

This study is subject to the usual limitations of response bias associated with a self-reported questionnaire. Although several measures were taken to mitigate this problem (i.e., ensuring anonymity and employing an online survey addressed directly to the authors), participants may have responded in a socially desirable manner.

In this study, we assumed that organisational commitment is an antecedent of OPC. However, other studies have found that organisational commitment is a consequence of the pressures faced due to OPC. Therefore, future studies analysing the effect of the pressures perceived by professional accountants on their commitment to the organisation would be of interest to the organisational behaviour literature.

\section{References}

Amat, O., \& Bové, J. M. (2015). El Experto Contable a nivel internacional1. Revista de Contabilidad y Dirección, 21, 21-40.

Aranya, N., \& Ferris, K. R. (1984). A reexamination of accountants' organizational-professional conflict. Accounting Review, 59(1), 1-15.

Aranya, N., Pollock, J., \& Amernic, J. (1981). An examination of professional commitment in public accounting. Accounting, Organizations and Society, 6(4), 271-280.

Ashforth, B. E., \& Mael, F. (1989). Social identity theory and the organization. Academy of Management Review, 14(1), 20-39.

Bamber, E. M., \& Iyer, V. M. (2002). Big 5 auditors' professional and organizational identification: Consistency or conflict?. Auditing: A Journal of Practice \& Theory, 21(2), 21-38. 
Bamber, E. M., \& Iyer, V. (2009). The effect of auditing firms' tone at the top on auditors' job autonomy, organizational-professional conflict, and job satisfaction. International Journal of Accounting \& Information Management, 17(2), 136-150.

Barrainkua, I., \& Espinosa-Pike, M. (2015). New insights into underreporting of time: The audit partner context. Accounting, Auditing \& Accountability Journal, 28(4), 494-514.

Barrainkua, I., \& Espinosa-Pike, M. (2018). The Influence of Auditors' Commitment to Independence Enforcement and Firms' Ethical Culture on Auditors' Professional Values and Behaviour. In C. Jefrey (Ed.). Research on Professional Responsibility and Ethics in Accounting (pp. 17-52). Emerald Publishing Limited.

Bobek, D. D., Hageman, A. M., \& Radtke, R. R. (2015). The influence of roles and organizational fit on accounting professionals' perceptions of their firms' ethical environment. Journal of Business Ethics, 126(1), 125-141.

Brouard, F., Bujaki, M., Durocher, S., \& Neilson, L. C. (2017). Professional accountants' identity formation: An integrative framework. Journal of Business Ethics, 142(2), 225-238.

Cooper, D. J., \& Robson, K. (2006). Accounting, professions and regulation: Locating the sites of professionalization. Accounting, Organizations and Society, 31(4), 415-444.

Davenport, L., \& Dellaportas, S. (2009). Interpreting the public interest: A survey of professional accountants. Australian Accounting Review, 19(1), 11-23.

Douglas, P. C., Davidson, R. A., \& Schwartz, B. N. (2001). The effect of organizational culture and ethical orientation on accountants' ethical judgments. Journal of Business Ethics, 34(2), 101-121.
Duska, R. F., Duska, B. S., \& Kury, K. W. (2018). Accounting ethics. Hoboken: Wiley-Blackwell.

Espinosa-Pike, M., \& Barrainkua, I. (2016). An exploratory study of the pressures and ethical dilemmas in the audit conflict. Spanish Accounting Review, 19(1), 10-20.

Espinosa-Pike, M., \& Barrainkua, I. (2017). El efecto de los valores profesionales y la cultura organizativa en la respuesta de los auditores a las presiones de tiempo. Spanish Journal of Finance and Accounting/Revista Española de Financiación y Contabilidad, 46(4), 507-534.

Espinosa-Pike, M., \& Barrainkua, I. (2019). Professional accountants in Spain: A comparative study of ethical and professional values. Spanish Journal of Finance and Accounting/Revista Española de Financiación y Contabilidad, 49(2), 234-264. doi: 10.1080/02102412.2019.1620491.

Fogarty, T. J. (1992). Organizational socialization in accounting firms: A theoretical framework and agenda for future research. Accounting, Organizations and Society, 17(2), 129-149.

Freidson, E. (1989). Theory and the Professions. Indiana Law Journal, 64(3), 423-432.

Garcia-Falières, A., \& Herrbach, O. (2015). Organizational and professional identification in audit firms: An affective approach. Journal of business ethics, 132(4), 753-763.

Gendron, Y., Suddaby, R., \& Lam, H. (2006). An examination of the ethical commitment of professional accountants to auditor independence. Journal of Business Ethics, 64(2), 169-193.

Gendron, Y., Suddaby, R., \& Qu, S. Q. (2009). Professional-organisational commitment: A study of Canadian professional accountants. Australian Accounting Review, 19(3), 231-248.

Hall, R. H. (1967). Some organizational considerations in the professional organizational relationship. Administrative Science Quarterly, 
12(3), 461-478.

Hall, M., Smith, D., \& Langfield-Smith, K. (2005). Accountants' commitment to their profession: Multiple dimensions of professional commitment and opportunities for future research. Behavioral Research in Accounting, 17(1), 89-109.

Harrell, A., Chewning, E., \& Taylor, M. (1986). Organizational-professional conflict and the jobsatisfaction and turnover intentions of internal auditors. Auditing-A Journal of Practice \& Theory, 5(2), 109-121.

Hatfield, R. C., Jackson, S. B., \& Vandervelde, S. D. (2011). The effects of prior auditor involvement and client pressure on proposed audit adjustments. Behavioral Research in Accounting, 23(2), 117-130.

Hiller, K., Mahlendorf, M. D., \& Weber, J. (2014). Management accountants' occupational prestige within the company: A social identity theory perspective. European Accounting Review, 23(4), 671-691.

International Federation of Accountants (2016). Handbook of the Code of Ethics for Professional Accountants. Retrieved from https://www. ethicsboard.org/international-code-ethicsprofessional-accountants

Larson, M. S. (1977). The Rise of Professionalism: A sociological analysis. Berkeley: University of Berkeley Press.

Lord, A., \& DeZoort, F.T. (2001). The impact of commitment and moral reasoning on auditors' responses to social influence pressure. Accounting, Organizations, and Society, 26(3), 215-235.

Martinov-Bennie, N., \& Pflugrath, G. (2009). The strength of an accounting firm's ethical environment and the quality of auditors' judgments. Journal of Business Ethics, 87(2), 237-253.
McGregor, C.C., Killough, L.N., \& Brown, R.M. (1989). An investigation of organizationalprofessional conflict in management accounting. Journal of Management Accounting Research, 1, 104-118.

McManus, L., \& Subramaniam, N. (2014). Organisational and professional commitment of early career accountants: Do mentoring and organisational ethical climate matter?. Accounting \& Finance, 54(4), 1231-1261.

Meixner, W. F. \& Bline, D. M. (1989). Professional and job-related attitudes and the behaviours they influence among governmental Accountants. Accounting, Auditing and Accountability Journal, 2, 8-20.

Mowday, R. T., Steers, R. M., \& Porter, L. W. (1979). The measurement of organizational commitment. Journal of vocational behavior, 14(2), 224-247.

Muzio, D., \& Kirkpatrick, I. (2011). Introduction: Professions and organizations - a conceptual framework. Current Sociology, 59(4), 389-405.

Parker, L. (1987). An historical analysis of ethical pronouncements and debate in the Australian accounting profession. Abacus, 23, 126-140.

Parsons, T. (1939). The professions and social structure. Social forces, 17(4), 457-467.

Porter, L. W., Steers, R. M., Mowday, R. T., \& Boulian, P. V. (1974). Organizational commitment, job satisfaction, and turnover among psychiatric technicians. Journal of applied psychology, 59(5), 603.

Shafer, W. E. (2002). Ethical pressure, organizational-professional conflict, and related work outcomes among management accountants. Journal of Business Ethics, 38(3), 261-273.

Shafer, W. E. (2009). Ethical climate, organizational-professional conflict and organizational commitment: A study of Chinese 
auditors. Accounting, Auditing \& Accountability Journal, 22(7), 1087-110.

Shafer, W. E. (2015). Ethical climate, social responsibility, and earnings management. Journal of Business Ethics, 126(1), 43-60.

Shafer, W. E., Lowe, D. J., \& Fogarty, T. J. (2002). The effects of corporate ownership on public accountants' professionalism and ethics. Accounting Horizons, 16(2), 109-124.

Shafer, W. E., Poon, M. C., \& Tjosvold, D. (2013). An investigation of ethical climate in a Singaporean accounting firm. Accounting, Auditing \& Accountability Journal, 26(2), 312-343.

Shafer, W. E., \& Simmons, R. S. (2011). Effects of organizational ethical culture on the ethical decisions of tax practitioners in mainland China. Accounting, Auditing \& Accountability Journal, 24(5), 647-668.

Shafer, W. E., \& Wang, Z. (2010). Effects of ethical context on conflict and commitment among Chinese accountants. Managerial Auditing Journal, 25(4), 377-400.

Sikka, P. (2004). Some questions about the governance of auditing firms. International Journal of Disclosure and Governance, 1(2), 186-200.

Suddaby, R., Gendron, Y., \& Lam, H. (2009). The organizational context of professionalism in accounting. Accounting, Organizations and Society, 34(3), 409-427.

Svanberg, J., \& Öhman, P. (2015). Auditors〉 identification with their clients: Effects on audit quality. The British Accounting Review, 47(4), 395-408.

Svanberg, J., \& Öhman, P. (2016). Does ethical culture in audit firms support auditor objectivity?. Accounting in Europe, 13(1), 65-79.

Treviño, L. K. (1990). A cultural perspective on changing and developing organizational ethics. Research in Organizational Change and Development, 4, 195-230.

Treviño, L. K., Butterfield, K. D., \& McCabe, D. L. (1998). The ethical context in organizations: Influences on employee attitudes and behaviours. Business Ethics Quarterly, 8(3), 447-476.

Wyatt, A. R. (2004). Accounting professionalismthey just don't get it. Accounting Horizons, 18(1), 45-53. 


\section{Appendix - Questionnaire}

\section{$\underline{\text { OPC }}$}

1. Pressures to issue financial or non-financial information that incorrectly represents the facts, including statements with respect to financial statements, tax and legal obligations, or requirements from the regulator

2. Pressures to intentionally lie or mislead the auditors or the regulator

3. Pressures to prepare or review financial statements without having the complete information needed

4. Pressures to omit information that could be relevant for users

5. Pressure to issue misleading financial information to meet investors', analysts', or creditors' expectations.

6. Pressures from superiors to reduce, in an inappropriate way, the amount of work done with the objective of reducing costs

7. Pressures from superiors to perform tasks without having the required skills or competence

8. Pressures from superiors, colleagues, or clients to present information that has been altered to increase their compensation

\section{Public interest commitment}

1. In the exercise of the accounting profession, public interest must always be above both personal interests and the interests of the client

\section{Profesional commitment}

1. I am extremely glad that I chose accounting over other professions that I was considering

2. I really care about the fate of the accounting profession

3. I am proud to tell others that I am an accountant

\section{Organizational commitment}

1. I am willing to put a great deal of effort beyond that normally expected in order to help this firm be successful

2. I talk up this firm to my friends as a great firm to work for

3. I find my values and the firm's values are very similar

\section{Organizational ethical culture}

1. Management in this organisation disciplines unethical behaviour when it occurs

2. People of integrity are rewarded in this organisation

3. Top managers of this organisation regularly show that they care about ethics

4. Ethical behaviour is the norm in this organisation

5. Top management of this organisation guides decision making in an ethical direction

6. Employees in this organisation perceive that people who violate the ethics code still get rewards

7. The ethics code serves only to maintain organisation's public image

8. Top managers in this organisation are models of unethical behaviour

9. Top managers in this organisation are concerned with informing employees about the ethics code

10. Top managers in this organisation promote the ethical training of employees 


\section{Authors:}

1. Itsaso Barrainkua, Doctor in Finance and Accounting, Lecturer at the University of the Basque Country, Bilbao, Spain.

E-mail: itsaso.barrainkua@ehu.eus

ORCID

(iD) 0000-0001-6118-9837

2. Marcela Espinosa Pike, Doctor in Finance and Accounting, Senior Lecturer at the University of the Basque Country, Bilbao, Spain.

E-mail: marcela.espinosa@ehu.eus

ORCID

(iD 0000-0002-2065-391X

\section{Contribution of each author}

\begin{tabular}{lcc}
\hline Contribution & $\begin{array}{c}\text { Itsaso } \\
\text { Barrainkua }\end{array}$ & $\begin{array}{c}\text { Marcela } \\
\text { Espinosa-Pike }\end{array}$ \\
\hline $\begin{array}{l}\text { 1. Definition of research problem } \\
\text { 2. Development of hypotheses or research questions (empirical studies) }\end{array}$ & $\sqrt{ }$ \\
3. Development of theoretical propositions (theoretical work) & $\sqrt{ }$ & $\sqrt{ }$ \\
4. Theoretical foundation / Literature review & $\sqrt{ }$ \\
5. Definition of methodological procedures & $\sqrt{ }$ & $\sqrt{ }$ \\
6. Data collection & $\sqrt{ }$ \\
7. Statistical analysis & $\sqrt{ }$ \\
8. Analysis and interpretation of data & $\sqrt{ }$ \\
9. Critical revision of the manuscript & $\sqrt{ }$ \\
10. Manuscript writing & $\sqrt{ }$ \\
11. Other (please specify which) & $\sqrt{ }$ & $\sqrt{ }$ \\
\end{tabular}

